ENTREPRENEURSHIP AND SUSTAINABILITY ISSUES

ISSN 2345-0282 (online) http://jssidoi.org/jesi/

2020 Volume 8 Number 2 (December)

http://doi.org/10.9770/jesi.2020.8.2(52)
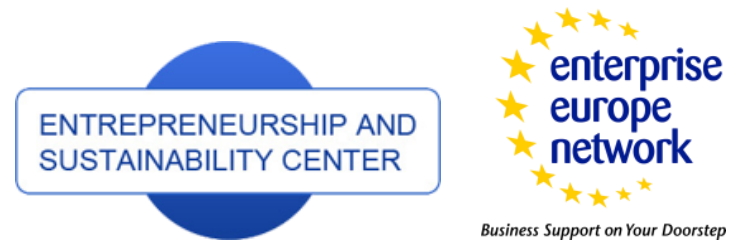

Business Support on Your Doorstep
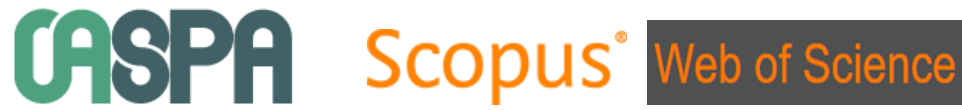

http://jssidoi org/esc/home

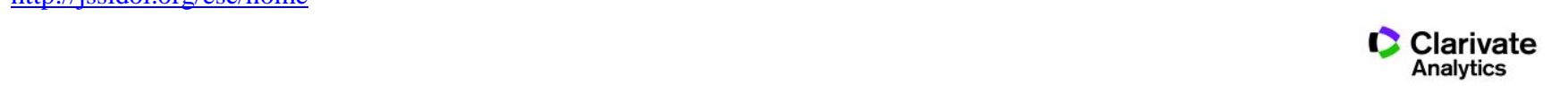

\title{
THE EFFECTS OF MANAGERIAL PERCEPTIONS ON CSR PRACTICES AND CORPORATE FINANCIAL PERFORMANCE: AN EVIDENCE FROM VIETNAM*
}

\author{
Khuong N. Mai ${ }^{1}$, Phuong N.D. Nguyen ${ }^{2 *}$, An K.T. Nguyen ${ }^{3}$, Ngoc M. Tran ${ }^{4}$ \\ 1,2,3,4 School of Business International University Ho Chi Minh City, Linh Trung Ward, Thu Duc District, HCMC, Vietnam \\ 1,2,3,4 Vietnam National International University Ho Chi Minh City, Vietnam \\ E-mails: ${ }^{1}$ mnkhuong@hcmiu.edu.vn ; ${ }^{2 *}$ nndphuong@hcmiu.edu.vn (Corresponding author); ${ }^{3}$ truongan@tdmu.edu.vn; \\ ㅎinhngoc031097@gmail.com
}

Received 15 March 2020; accepted 20 September 2020; published 30 December 2020

\begin{abstract}
Corporate Social Responsibilities (CSR) and the related topics have evolved to be the major considerations in Western and developed countries. However, this concept as well as practical application is still new in developing nations and insufficient researches addressing CSR issues. This paper aims to fill the missing gap of managerial perceptions towards CSR practices and Corporate Financial Performance (CFP) by investigating the effects of managerial perception on CSR practices and the financial outcomes reported by the managers. Following the quantitative approach, the surveys were distributed to 869 managers currently working at Ho Chi Minh City and Binh Duong Province (Vietnam) based companies doing business in different sectors, with different sizes and industries. The collected data were processed through the factor analysis and SEM. As the results, managerial perceptions serve as the powerful forces for CSR implementation. Among the four remaining CSR domains, economic responsibility is the top contributor to CFP while legal, philanthropic and environmental dimensions showed minor impacts. Several implications are provided at the end to facilitate enterprises' decision making process and governments' strategy to foster the CSR adoption status domestically.
\end{abstract}

Keywords: managerial perceptions; CSR practices; CSR financial performance; Vietnam

Reference to this paper should be made as follows: Mai, K.M., Nguyen , P.N.D., Nguyen, A.K.T., Tran, N.M. 2020. The effects of managerial perceptions on csr practices and corporate financial performance: an evidence from Vietnam. Enterpreneuship and Sustainability Issues 8(2), 858-874. http://doi.org/10.9770/jesi.2020.8.2(52)

JEL Classifications: Q56, L25

\footnotetext{
* This research is funded by Vietnam National University Ho Chi Minh City (VNU-HCM) under grant number B2020-28-03
} 


\section{ENTREPRENEURSHIP AND SUSTAINABILITY ISSUES}

ISSN 2345-0282 (online) http://jssidoi.org/jesi/

2020 Volume 8 Number 2 (December)

http://doi.org/10.9770/jesi.2020.8.2(52)

\section{Introduction}

Globalization has urged and empowered rational individuals to actively demand higher values contributed by operating business entities. According to Barnett and Salomon (2006), investors are strictly asking companies for financial growth in addition with societal development, even though the two tasks are believed to move in opposite way. The notion of Corporate Social Responsibility (CSR) has been mentioned frequently throughout history referring and debating about the true role of corporation in essence extending merely supplying goods and services and earning profits (economic responsibilities) and complying to laws (legal responsibilities). Factors shaping the decision whether to engage in CSR activities are but not limited to internal executive incentives (Deckop et al., 2006) and external stakeholder pressures (Agle et al., 1999). Notably, determining how CSR implementation affects company's bottom lines is an unceasing effort of numerous researchers because business leaders are supposed to critically base on financial motivation to make decisions. According to the Stakeholder Theory developed by Freeman (1984), CSR engagement can help companies yield financial interests mediated by trustful and healthy relationships with the public. Du et al (2013) added that external stakeholders in turn can experience better total welfare thanks to company's strategic CSR. However, the mixed results from studies examining the connection between CSR practices and Corporate Financial Performance (CFP) occur due to differences in research methodology (Famiola and Wulansari, 2019; Margolis and Walsh, 2003; Menassa and Dagher, 2019) as well as studied context (Hofstede, 1980; Singh and Mittal, 2019) which may impact managers' attitudes towards CSR and their actions (Batool et al., 2016; Nguyen et al., 2015; Waldman et al., 2006).

Although CSR-related papers are high in quantity in Western countries, there is still a dearth of researches taking developing nation contexts (Kisenyi and Gray, 1998), especially in Vietnam. The term CSR has appeared in Vietnam since the introduction of international companies who brought along their "Code of conducts" to ensure the coherence in their strategic management. Despite the fact that this integration has gradually been observed and adopted by domestic giants, still CSR implementation is not sufficiently paid attention because 98 percent of the current companies are small and medium in size (General Statistics of Vietnam, 2019) and have limited resources (Nguyen et al., 2015). Scandalous cases relating to legal transgression, ethical standards violation or environmental destruction still occur directly and indirectly threatening the quality of life. Several previous studies about CSR in Vietnam has been found, yet the general theme has not been addressed. Studies by Tran (2017) and Thanh et al. (2018) considered CSR practices at Small and Medium Enterprises (SMEs). Other researchers investigated the link of social responsibilities performed by corporations to consumers' attitudes and behaviors (Johar and Pham, 1999). Ho and Yekini (2014) found the positive causal nexus of CSR and CFP in Vietnam through their content analysis of 60 annual reports of 20 enterprises in 3 consecutive years. This paper also aims to clarify the impacts of CSR dimensions on financial performance, however, in another approach that exploring managers' perception towards CSR and their self-evaluation of the correlated CFP. In the paper, CSR literature will be carefully reviewed to build comprehensive conceptual model and form hypotheses. Four out of five dimensions employed to cover CSR practices are directly adopted from Carroll's Pyramid of CSR including Legal, Economic, Ethical and Philanthropic dimensions and the newly added Environmental dimension helps clearer demonstrate the current circumstances in Vietnam. According to Bortree (2014), environmental awareness has become one of the most notable facets of CSR disclosure due to high level of environmental concerns. More research focus on environmental responsibility and this topic has been receiving increase attention from academics and professions (Overton, 2018; Li et al., 2020). Further, engaging in environmental CSR practices indicates positive evaluation for CSR program of companies (Wahba, 2008) and gains good brand image (Planken et al., 2013). More importantly, environmental CSR implementation addresses stakeholder concerns for environmental challenges (Welford et al., 2008). Not only the government but also primary stakeholders have pressure on companies' activities related to protecting natural environment (Martínez García de Leaniz et al., 2019). Thus, companies in developing or developed countries cannot deny the visibility and importance of environmental CSR practices in their business performance. However, studies of relationship between 


\section{ENTREPRENEURSHIP AND SUSTAINABILITY ISSUES}

ISSN 2345-0282 (online) http://jssidoi.org/jesi/

2020 Volume 8 Number 2 (December)

http://doi.org/10.9770/jesi.2020.8.2(52)

environmental CSR practices and financial outcomes provide inconclusive results (Ambec and Lanoie, 2008). Research is needed to understand effects of environmental CSR practices on business performance in different contexts. Acknowledging the importance of environmental CSR practice, the researchers aimed to add this dimension to research model for testing its effects in the particular context of Vietnam economy. Throughout the research, the following objectives will be completed: (1) to demonstrate the managers' perception towards CSR in Ho Chi Minh City and Binh Duong Province; (2) to review the related literature body about CSR practices and CFP; (3) to provide a framework addressing CSR practices and CFP in managerial perspective; (4) to discover the link between each dimensions of CSR practices on CFP; (5) to give recommendations to conduct effective CSR activities and gain financial success.

\section{Literature review}

The emergence of CSR has been traced back to the 1950s when dozens of theoretical and practical debates about the most comprehensive CSR definition were found. Bowen and Johnson (1953) defines CSR as the obligations, decisions and actions of businessmen that bring values to the society rather than company's short term profits. Discussions about the pros and cons as well as applications of CSR have also been addressed widely in huge number of researches with different approaches and methodologies, each with its own limitations. To depict a holistic view of CSR and specify what types of responsibility firms have to performed, Carroll (1991) came up with "the most well-known model of CSR" or the so-called "four-part definitional framework for CSR" incorporating four conceptually independent domains arranged on a pyramid. Each dimension will be reviewed and discussed later. In addition to Carroll (1991) model, Dahlsrud (2008) in his content analysis of 37 definitions of CSR attempted to draw the common patterns and categorize CSR into five explicit dimensions that are voluntariness, stakeholder, social, environmental and economic by using frequency counts. This research is going to adopt five components of CSR in which four are retrieved from Carroll's Pyramid of CSR and one additional environmental dimension from Dahlsrud (2008). Thus, it is generally understood that CSR aims to gain financial success in the manner of ethical virtue, respect involved stakeholders and environment as a whole. Besides, although different perceptions and subjects such as corporate social performance (CSP), business ethics and corporate citizenships are reviewing substantially, the CSR concept is still considered as the mainstay and employed extensively in modern businesses.

A number of researches circumscribing CSR topic have raised few questions about the managerial role in initiating and organizing socially responsible actions (Wood, 1991), despite the fact that top managers were supposed to take crucial roles regarding to this field (Quazi, 2003). In detail, (Waldman et al., 2006) and Wood (1991) argued that it is socially responsible manager inducing the whole corporation to be socially responsible. The decision made by this type of manager seemed to be toughing since the balance of corporate objectives as well as internal stakeholders' interests and social responsibilities forces the leader to weigh, deliberate and harmonically integrate to the business with the established strategy (Marta et al., 2008). At the very first phase of the process, managers need to sense the signals transmitted from the external environment (Hegarty and Tihanyi, 1999) before contemplating on the set of responses (Child, 1972). This is when individual perception joins in to orchestrate the process as it is referred to the energetic emotional manner liable for appearing to, consolidating, and inferring sensory data (Buchanan and Huczynski, 1997). Building on this definition, Álvarez and Merino (2008) defined managerial perceptions as "the substratum" closely linking to managers' personal characteristics and serving as the foundation for determine the best alternative. Furthermore, managers' attitudes, knowledge and judgement are said to be moulded by their mental models built from personal unique values, beliefs, education, demography, backgrounds and cognitive predisposition (Harrisson and Boyle, 2006; Hill and Levenhagen, 1995; Rokeach, 1973; Menon and Menon, 1997; Senge and Sterman, 1992; Thomas and Simerly, 1994) which possibly suffers from inevitable human errors, biases and imperfection. For instance, Burton and Hegarty (1999) research revealed that women are more likely to engage to CSR orientation. Campbell (1999) presented that the more risk- 


\section{ENTREPRENEURSHIP AND SUSTAINABILITY ISSUES}

ISSN 2345-0282 (online) http://jssidoi.org/jesi/ 2020 Volume 8 Number 2 (December) http://doi.org/10.9770/jesi.2020.8.2(52)

avoidance tendency of the managers, the less opportunity they advance enviropreneurial marketing strategies. Thus, no manager can totally visualize and interpret the complicated business world in general and organizational system in particular (Simon, 1957). Yet, the better the upper echelon understands the environment, the better the organization performs (Downey et al., 1975; Hegarty and Tihanyi, 1999). By contrast, irrelevant interpretations of the environment can lead to catastrophic consequences (Milliken and Lant, 1990). Further researches also proved that top executives exert their power to launch and lead organization's CSR orientation as they oversee and guide the business to sustainable success (Banerjee, 2001; Waldman et al., 2006). Thomas and Simerly (1994) acknowledged that managers' perceptions play decisive role in disclosing the so-called "strategic posture" of the business describing decision makers' approach towards social demands. Ullmann (1985) stated that an active strategic posture nurtured by leader who attempts to gratify the majority of stakeholders by social responsibility exercises highly urges business to perform actual practices and disclosures. Peterson and Jun (2009) developed "the practitioner-based model of societal responsibilities" to come up with the model of managers' perspective in relation to societal responsibility. In spite of acquiring the inconsistent answers due to individual differences, the findings display the popular traditional or narrow view of managers towards CSR that instead of concerning the destiny of the world, most managers focus on responsibilities directly relating to the operations. In 2002, PricewaterhouseCoopers (PwC) surveyed 1200 CEOs from 33 countries to probe their perspective towards CSR. $70 \%$ of the participants admitted the vital role of CSR to their business no matter what economic stage they were in. In the 17th Annual Global CEO Survey (2017), PwC expanded the scope to 1344 CEOs in 68 countries to investigate their attitude towards CSR and Sustainability. Viewpoints about megatrends were classified into five groups: technological advances, demographic shifts, global economic power shift, resource scarcity and climate change, and urbanisation. The responses to the presented issues and challenges manifested managers' sustainableoriented mind-set. As exhibited in the report, among all CEOs, $76 \%$ of them conceived that it is important to fulfil societal needs and assure well-being of the descendants (PwC 17th Annual Global CEO Survey) and 69\% believed that business should balance all stakeholders' interests as it truly functions for. Recognizing the necessity of CSR, a lot of companies invent the titles such as "Corporate Responsibility Officer", "Vice President/Director of CSR", "Chief Compliance Officer", "Chief Ethics Officer" and "Investor Relations Officer" (Marshall and Heffes, 2007) to handle CSR affairs. In developing countries, personal values of managers are also described as the top internal pressure impelling corporate CSR engagement (Fernando and Lawrence, 2014). To sum up, managers' perceptions play the influential role in creating organization's awareness of CSR and cascading it to the lower level managers (Bedeian, 2002). Then, the way organization counters those issues closely connects to its singular features and culture (Bowen and Heath, 2005).

H1: Managerial perception is positively related to CSR practices

H1-1: Manager's perception is positively related to Economic CSR

H1-2: Manager's perception is positively related to Legal CSR

H1-3: Manager's perception is positively related to Ethical CSR

H1-4: Manager's perception is positively related to Philanthropic CSR

H1-5: Manager's perception is positively related to Environmental CSR

H2: Managerial perception is positively related to Corporate financial performance

According to Carroll (1991), economic dimension refers to the fundamental role of corporations that is to generate revenue and profit to sustain and develop their business by providing goods and services. This dimension may seem unusual at first because it does not clearly demonstrate the business's contribution to the society. However, profits are urgent topics since not only shareholders and board of management are directly incentivized by financial returns but external stakeholders can also expect the values creation that benefits them while businesses strive to achieve financial objectives. Moreover, resource shortage can possibly hinder CSR performing motivation. 


\section{ENTREPRENEURSHIP AND SUSTAINABILITY ISSUES}

ISSN 2345-0282 (online) http://jssidoi.org/jesi/

2020 Volume 8 Number 2 (December)

http://doi.org/10.9770/jesi.2020.8.2(52)

H3-1: Economic CSR is positively related to corporate financial performance.

Carroll (1991) also defines legal dimension as the company complying with laws whilst chasing to accomplish company's mission and vision. Companies that proactively follow different types of laws such as labor, taxation, business laws are regarded as performing legal responsibilities. Once companies decide to fulfill the dictated regulations, they need to incur the so-called compliance cost. On the contrary, companies might face the cost of non-compliance such as litigation, compensation and fines and other immeasurable costs in case they fail to obey laws. Comparing the cost of compliance and cost of non-compliance is a critical action although these two types of cost often vary across nations and industry which can lead to a certain tendency towards laws conformity. Based on the final results disclosed by Ponemon Institute and Global Scape Security Company, the costs of noncompliance are approximately 2.7 times as much as the costs companies must pay to adapt to regulations. By and large, besides explicit costs companies will unfortunately confront since violating legal requirements, there are incalculable losses they are subjected to listed as brand ruin, customers' distrust and other opportunity costs that takes them abiding years to completely recover.

H3-2: Legal CSR is positively related to corporate financial performance.

According to Irshad et al. (2007), this ethical CSR dimension refers to controlling social mores including moral standards, guidelines, values and desires of the society such as fair and just behavior for an operating business. The ethical responsibility differs from legal responsibility as the latter cannot fully encompass the multi-facets of ethics and morals (Solomon, 1994) and companies virtually need to auto-adjust themselves to the standards set by the society rather than the laws solely. Indeed, government regulations and laws derived from the urge from the society to clearly stipulate which action is right and which one is unacceptable in a particular culture and thus, is the subset of ethical responsibilities. Ethical CSR are apparently exhibited through company's respects to the stakeholder by operating with integrity, voluntary fair protection as well as human rights reverence.

H3-3: Ethical CSR is positively related to corporate financial performance.

Philanthropic responsibility - also denoted as Discretionary responsibility comprises entire types of voluntary corporate giving such as resources donation, fundraisings and other altruistic activities. As shown by the name, companies can decide whether to engage in philanthropic responsibilities without being judged and criticized by the populace (Jamali and Mirshak, 2006). However, a company satisfying this highest expectation of the society is promised to experience positive values due to being recognized as a good corporate citizen that reciprocates a portion of corporate wealth to the society which provides necessary conditions for them to thrive (Bowie, 1995). Despite that trade-off effect can happen as the expenses for philanthropy may strain company's bottom line (McWilliams and Siegel, 1995), still there are researchers such as Brammer and Millington (2008) proving that effective philanthropic CSR boosts CFP thanks to positive brand image and supports received from government, suppliers, employees and customers.

H3-4: Philanthropic CSR is positively related to corporate financial performance.

The environmental dimension of CSR practices is newly added as an independent dimension by this paper based on Dahlsrud (2008) content analysis of CSR definitions. The reason for this adoption comes from the substantial awareness and attention to environmental element from global consumers in the era of the Fourth Industrial Revolution and companies transforming to green businesses can reinforce their competitive advantages (Yusoff et al., 2015). According to Wang (2011), environmental CSR shows the endeavors and commitments from the company to preserve the natural resources as well as to protect the ecosystem during manufacturing products and delivering goods and services. The relationship between Environmental CSR and CFP has been 
addressed frequently by the literature. Russo and Fouts (1997) supported the progressive nexus of environmental responsibilities and financial performance by arguing that environmental friendly companies generate favorable feelings from consumers, avoid potential risks from being fined by the government and save resources for sustainable development.

H3-5: Environmental CSR is positively related to corporate financial performance.

Based on discussed literature review, previous theoretical framework and empirical studies, a conceptual model for this study was proposed. The main constructs in the model are manager's perception towards CSR, economic CSR, legal CSR, ethical CSR, philanthropic CSR, environmental CSR and Corporate Financial Performance (CFP). Figure 1 demonstrates the assumed underlying relationships, which was built based on strong foundation of theories.

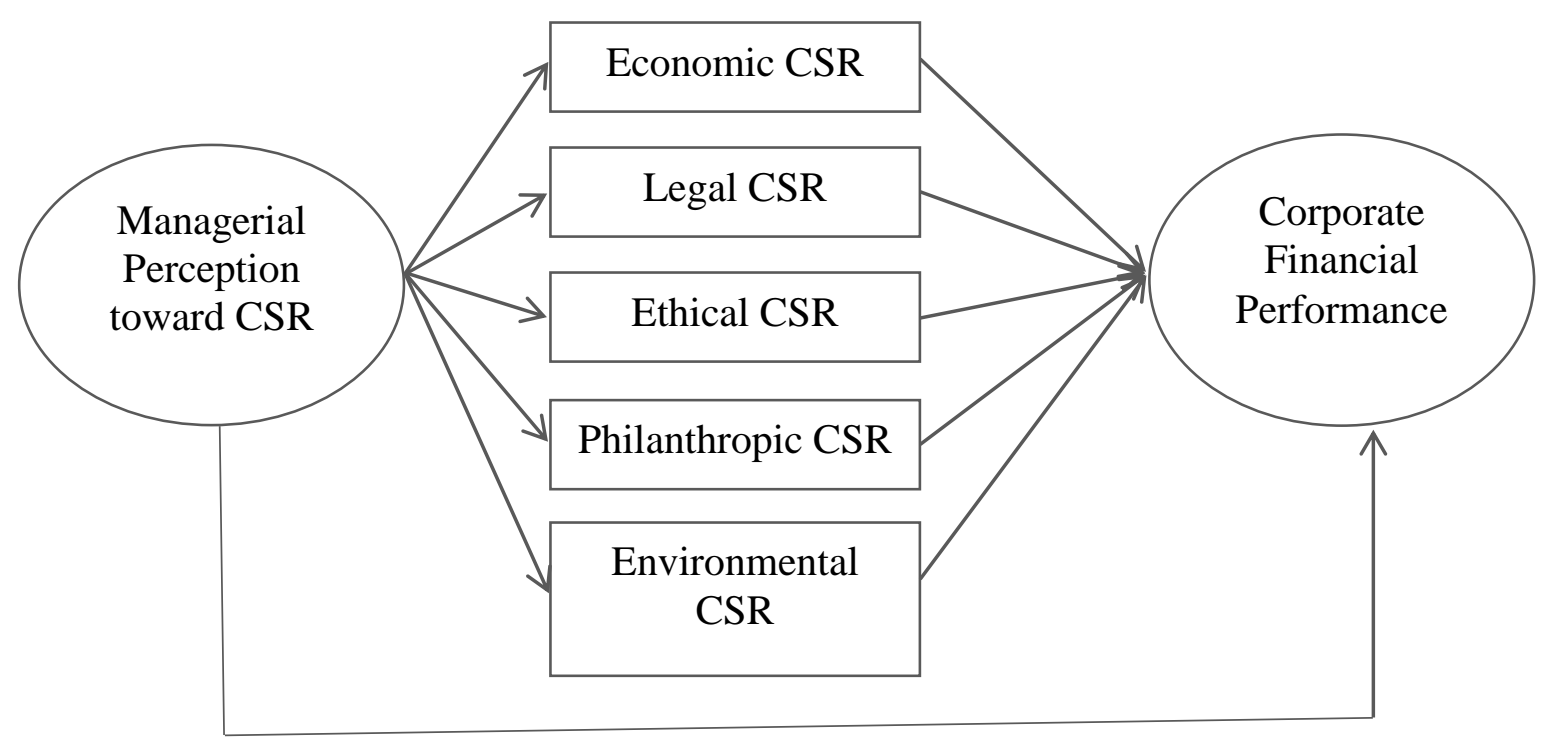

Figure 1. Proposed conceptual framework.

\section{Methodology and data}

Quantitative method will be used to ensure the objectiveness of collected data after statistically, mathematically and numerically analyzing. Also, in case of mapping the relations of among constructs, quantitative method is perfectly applicable. Managers working in different industry in two major locations of Vietnam - Ho Chi Minh City and Binh Duong were randomly surveyed. However, the sample will first be stratified into three major groups according to type of company they are coming from: Public, Private and FDI. CFP was constructed using a 3-item, 5-point Likert scale varied from 1 (strongly disagree) to 5 (strongly agree) in which 6 items were generated to measure managers' perceptions, 7 items to weight economic CSR, 5 items to quantify legal CRS, 5 items to measure ethical CSR, 5 items to measure philanthropic CSR, 7 items to measure environmental CSR and 3 items to measure CFP. Each item is an attitude measuring statement probing how managers evaluate the degree of CSR participation as well as financial performance in three latest fiscal years by themselves. The measurement scale was designed based on distinctive sources for each constructs and combined together. CFP was primarily measured by sales, return on equity (ROE) and return on assets (ROA) described by managers' level of agreement. The initial questionnaire was firstly composed in English and then converted into Vietnamese for use. 


\section{ENTREPRENEURSHIP AND SUSTAINABILITY ISSUES}

ISSN 2345-0282 (online) http://jssidoi.org/jesi/

2020 Volume 8 Number 2 (December)

http://doi.org/10.9770/jesi.2020.8.2(52)

A total of 869 valid answers were received after distributing the questionnaire to the target sample. Online questionnaires were sent to the Departments of Planning and Investment of two selected cities for distribution to targeted managers. Furthermore, printed surveys were also spread to accessible managers in nearby companies in Ho Chi Minh City. Then, face and content validity using SPSS was executed to ensure reliability measuring scale from 38 to 33 items, 5 items of ethical CSR were eliminated due to low factor loadings before establishing SEM using AMOS. In details, before conducting EFA to identify the latent factors, the reliability test for each individual construct was employed. Cronbach's Alphas were restated again after the authors ended up with the underlying factors. Next, the Confirmatory Factor Analysis (CFA) - a multivariate statistical procedure was executed to test how well latent variables in the prerequisite stage represent the constructs. After CFA, firm evidence will be provided to reinforce hypotheses testing results. This study adopted principal component analysis (PCA) as the method for SEM analysis. According to Diamantopoulos et al. (2000), model fit is evaluated by the series of indices: Chi-square / Degree of Freedom (CMIN/df), p-value, Root Mean Square Residual (RMR), Comparative Fit Index (CFI), Goodness of Fit Index (GFI), Tucker and Lewis Index (TLI), Root Mean Square Error of Approximation (RMSEA) and Akaike Information Criterion (AIC) which are well suited for Structural Equation Modeling (SEM).

\section{Results and discussions}

Results from descriptive statistics revealed that the sample is greatly diverse as surveyed managers came from companies in different business sectors, types, sizes with different annual revenue and positions. As shown in Table 1, the representatives from Ho Chi Minh City based companies (62.37\%) outnumbered ones from Binh Duong Province (37.63\%). Most respondents are Deputy Managers (25.20\%) and only a few of them are Chief Accountant (6.67\%). More than half of the sample is currently working in Private business sector (59.26\%) and this is also the case for business size which the size of 10 to 200 employees made up 58.92\% of the three classifications. Almost half of the sample (43.27\%) fell into business type of "Trade and Services"; the other "Real Estate" and "Manufacturing" respectively account for $17.03 \%$ and $39.70 \%$. In terms of annual revenue, the highest percentage of respondents $38.67 \%$ shared that their companies earn from 11 to 50 billion VND, while $25.09 \%$ is for " $50-200$ billion VND", $18.30 \%$ for " 1 to 10 billion VND" and $17.95 \%$ for " 200 billion VND and above" listed in descending order. Because the sample demography somehow captures the business environment here in the two typical commercial areas in the South that are considered to be pioneers in CSR adoption, it is endorsed by the authors to realistically reflect the overall characteristics of business in Vietnam.

As mentioned previously, an EFA with the calibrated sample of 869 using PCA approach with Varimax method of rotation was employed to diminish the number of initial observed variables and find the latent components. The number of extracted factors is determined by the the number of eigen-values exceeding 1.0. Moreover, in case the factor loadings of an item happened to be less than 0.4 (Hair et al., 1998) or cross-loadings appeared to be greater than 0.3 (Jabnoun and Al-Tamimi, 2003) between two arbitrary items, the item(s) were eliminated. Table 3 presents a four-CSR factor underlying structure labeled as Environmental CSR, Legal CSR, Economic CSR and Philanthropic CSR which together explained $51.976 \%$ of the total variance was obtained after two rounds of examination and item removal. Besides the whole Ethical CSR pillar was deleted, EcoCSR5 and EcoCSR7 were also excluded as not passing the predetermined constraints. The Cronbach's Alpha was run again for the Economic CSR dimension (0.737) and satisfied the lower limit of 0.70 (Hair et al., 2010). The authors conclude that the overall scale and the four extracted factors are validated to be reliable. The final KMO of 0.944 after dropping 7 items was recognized as "Marvelous" and the p-value from Bartlett's test of sphericity (0.000) lower than 0.05 or $5 \%$ confirm that the results of factor analysis were useful. 


\section{ENTREPRENEURSHIP AND SUSTAINABILITY ISSUES}

ISSN 2345-0282 (online) http://jssidoi.org/jesi/ 2020 Volume 8 Number 2 (December) http://doi.org/10.9770/jesi.2020.8.2(52)

Subsequently, a CFA was employed on the validated sample of 869 to test whether the CFA model and the data structure are acceptably fit with each other. The fit indices of the measurement model are demonstrated and evaluated in Table 1.

The results from Table 4 verified that the measurement model was fitted to all indices $(\chi 2=2.475$, df $=203, p=$ $.000, \mathrm{GFI}=.947, \mathrm{TLI}=.945, \mathrm{CFI}=.951, \mathrm{RMSEA}=.041)$. Also, there are no distinguishing differences between CFA (SFL) and EFA loadings, indicating that the structure of CSR practices after the EFA was generally validated in the CFA.

Table 1. Summary of factor analysis and feasibility analysis

\begin{tabular}{|c|c|c|c|c|}
\hline \multirow[b]{2}{*}{ Factor and measured items } & EFA $(n=869)$ & \multicolumn{3}{|c|}{ CFA $(n=869)$} \\
\hline & Loading & SFL & SMC & $\begin{array}{l}\text { Composite } \\
\text { Reliability }\end{array}$ \\
\hline \multicolumn{5}{|l|}{ Environmental CSR (Cronbach's Alpha $=.837$ ) } \\
\hline EnCSR4: Use of eco-friendly materials & .707 & .673 & .452 & \multirow{7}{*}{.838} \\
\hline EnCSR6: Minimize and recycle wastes & .675 & .672 & .451 & \\
\hline EnCSR5: Reduce energy consumption & .668 & .665 & .443 & \\
\hline EnCSR3: Avoid pollution & .645 & .633 & .401 & \\
\hline EnCSR7: Environmental label of products & .619 & .664 & .441 & \\
\hline EnCSR1: Programs of minimizing negative impacts & .595 & .628 & .395 & \\
\hline EnCSR2: Protect and improve natural environment & .595 & .629 & .395 & \\
\hline \multicolumn{5}{|l|}{ Legal CSR (Cronbach's Alpha $=.789)$} \\
\hline LeCSR4: Currently issued laws & .739 & .621 & .386 & \multirow{5}{*}{.754} \\
\hline LeCSR2: Legal regulations & .716 & .700 & .489 & \\
\hline LeCSR1: Paying taxes & .630 & .644 & .415 & \\
\hline LeCSR5: Respects of agreement & .620 & .668 & .447 & \\
\hline LeCSR3: Legal standards of products & .603 & .639 & .408 & \\
\hline \multicolumn{5}{|l|}{ Economic CSR (Cronbach's Alpha $=.737)$} \\
\hline EcCSR1: Profitability & .738 & .550 & .302 & \multirow{5}{*}{.740} \\
\hline EcCSR4: Benefits for employees & .587 & .678 & .459 & \\
\hline EcCSR3: Productivity & .550 & .623 & .389 & \\
\hline EcCSR2: Creating jobs & .483 & .575 & .331 & \\
\hline EcCSR6: Customer satisfaction & .458 & .580 & .336 & \\
\hline \multicolumn{5}{|l|}{ Philanthropic CSR (Cronbach's Alpha $=.751)$} \\
\hline PhiCSR2: Collaboration with local businesses & .711 & .577 & .333 & \multirow{5}{*}{.752} \\
\hline PhiCSR5: Dedication to society development & .662 & .642 & .412 & \\
\hline PhiCSR4: Support community & .649 & .632 & .400 & \\
\hline PhiCSR3: Charities & .524 & .641 & .411 & \\
\hline \multirow[t]{2}{*}{ PhiCSR1: Support education } & .508 & .579 & .336 & \\
\hline & $\begin{aligned} \mathrm{KMO}=.944, \text { Bartlett's test } \\
\\
\text { of sphericity: } \\
\chi 2=6333.909, \mathrm{p}<.000\end{aligned}$ & \multicolumn{3}{|c|}{$\begin{array}{c}\chi^{2}=2.475, \mathrm{df}=203, \mathrm{p}=.000 \\
\mathrm{GFI}=.947, \mathrm{TLI}=.945, \mathrm{CFI}=.951 \\
\text { RMSEA }=.041\end{array}$} \\
\hline
\end{tabular}

Note: EFA = Exploratory Factor Analysis; CFA = Confirmatory Factor Analysis; SFL = Standardized Factor Loading; SMC = Squared Multiple Correlation; KMO = Kaiser-Meyer-Olkin Measure of Sampling Adequacy; RMSEA = Root Mean Square Error of Approximation; GFI = Goodness of Fit Index; TLI = Tucker-Lewis Index; CFI = Comparative Fit Index

Six items of managerial perception variables and three items of CFP were run with another EFA with the same calibrated sample size of 869. As the expectations, two independent factors were extracted which explained for $55.624 \%$ of the initial observed variables. Only one round was run and no items violated that presets (See Table 2). The Cronbach's Alphas all passed the limit of 0.6 as suggested by Diamantopoulos et al. (2000), showing a strong degree of reliability. Again, KMO and p-values from Bartlett's test of sphericity confirm the usefulness of results retrieved from factor analysis. 
Moreover, Table 2 indicates that the measurement model of Managerial Perception and CFP fit the data well by comparing the extracted indices with the thresholds.

Table 2. Factor Analyses of Managerial Perceptions and CFP

\begin{tabular}{|c|c|c|c|c|}
\hline \multirow[b]{2}{*}{ Factor and measured items } & $\operatorname{EFA}(n=869)$ & \multicolumn{3}{|c|}{ CFA $(n=869)$} \\
\hline & Loading & SFL & SMC & $\begin{array}{l}\text { Composite } \\
\text { Reliability }\end{array}$ \\
\hline \multicolumn{5}{|c|}{ Managerial Perception (Cronbach's Alpha $=.808$ ) } \\
\hline Percep5: Access to bank loans & .714 & .615 & .378 & .801 \\
\hline Percep3: Long term profitability & .687 & .710 & .505 & \\
\hline Percep2: Relationship with the government & .659 & .652 & .424 & \\
\hline Percep1: Company image & .607 & .577 & .333 & \\
\hline Percep6: Avoid additional regulations & .606 & .590 & .348 & \\
\hline Percep4: Industry-labor relation & .505 & .657 & .431 & \\
\hline \multicolumn{5}{|c|}{ Corporate Financial Performance (Cronbach's Alpha $=.706)$} \\
\hline FP2: Return on sales & .816 & .694 & .482 & .707 \\
\hline FP1: Return on equity & .617 & .638 & .407 & \\
\hline \multirow[t]{2}{*}{ FP3: Return on assets } & .566 & .671 & .451 & \\
\hline & $\begin{array}{c}\mathrm{KMO}=.855, \text { Bartlett's test of } \\
\text { sphericity: } \chi 2=2145.360, p<.000\end{array}$ & \multicolumn{3}{|c|}{$\begin{array}{l}\chi 2=3.395, \mathrm{df}=25, \mathrm{p}=.000 ; \mathrm{GFI}=.978 \\
\mathrm{TLI}=.959, \mathrm{CFI}=.972, \mathrm{RMSEA}=.053,\end{array}$} \\
\hline
\end{tabular}

In addition, the Chi-Square decreasing from 138.020 to 84.876 exhibited in Table 2 was the result obtained after taking the cross-loading of Percept5 and Percept6 basing on their highest modification indices (Nyaupane et al., 2004). It can be reasonably rationalize that a socially responsible company believed to less suffer from harsh governmental regulations can coincidently attain better credits to financial institutions. Apart from the decrease in Chi-Square, the model fit indices all significantly improved and the loadings from the CFA emphasize the significance of the model at the 0.05 level after EFA.

After proving that the measurement model was acceptable, it is essential to establish the structural equation model (SEM) with the sample size of 869 . The factors' scores were computed by taking the mean of each factor. The structural model is presented in Figure 2 below. 


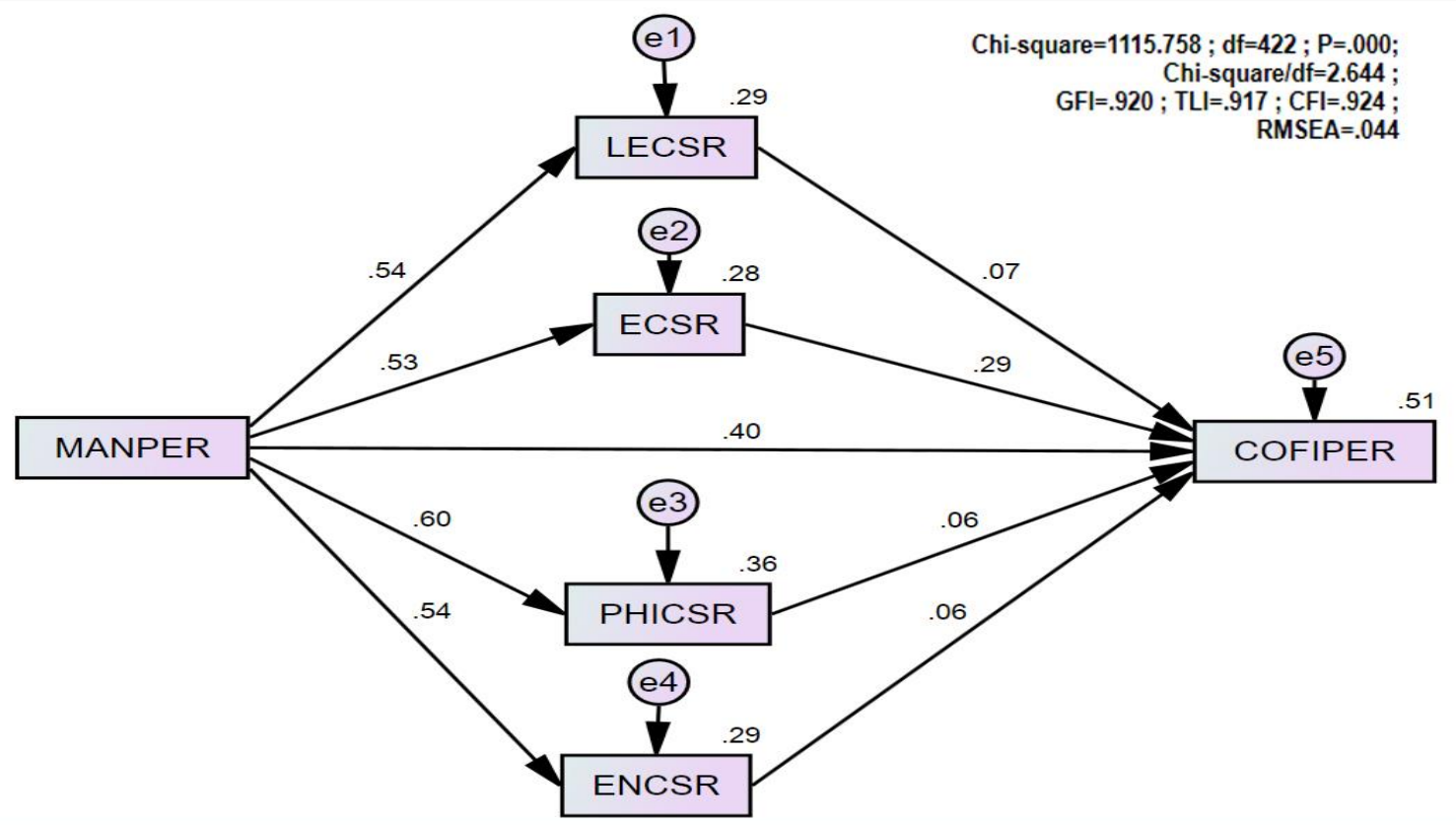

Figure 2. Modified Structural Model with Estimated Path Coefficient

According to the path coefficients shown in Figure 2, managerial perceptions toward CSR practices had significantly positive association with all four CSR dimensions comprising legal, economic, philanthropic and environmental responsibilities which then formed positive influences on CFP. Thus, hypothesis 1 (H1-1, H1-2, H1-3, H1-4; H1-5) and hypothesis 2were supported. Additionally, the direct relationship between Managerial Perceptions and CFP was also portrayed with the coefficient of 0.4 confirming that the secondary hypothesis 3 was also accepted. Based on the results from the connection among constructs, the authors can conclude that managerial perceptions towards CSR practices had positively indirect relationship with CFP through promoting the implementation of CSR in the four categories. In other words, once managers are clearly aware of the benefits receiving from CSR engagement, they are more willing to actually execute CSR activities and gain better financial performance in terms of ROA, ROE and Sales increase (See Table 3).

Table 3. Hypothesis Testing Results

\begin{tabular}{|l|l|c|c|c|c|c|}
\hline & \multicolumn{1}{|c|}{ Path } & Direct Effect - St. Estimate $(\beta)$ & S.E & C.R. & P & Result \\
\hline H1-1 & MANPER $\rightarrow$ ECSR & .533 & .018 & 18.548 & $* * *$ & Supported \\
\hline H1-2 & MANPER $\rightarrow$ LECSR & .542 & .018 & 19.015 & $* * *$ & Supported \\
\hline H1-4 & MANPER $\rightarrow$ PHICSR & .602 & .017 & 22.208 & $* * *$ & Supported \\
\hline H1-5 & MANPER $\rightarrow$ ENCSR & .538 & .018 & 18.781 & $* * *$ & Supported \\
\hline H2 & MANPER $\rightarrow$ COFIPER & .403 & .037 & 10.173 & $* * *$ & Supported \\
\hline H3-1 & ECSR $\rightarrow$ COFIPER & .292 & .043 & 10.388 & $* * *$ & Supported \\
\hline H3-2 & LECSR $\rightarrow$ COFIPER & .072 & .043 & 2.554 & $.011^{*}$ & Supported \\
\hline H3-4 & PHICSR $\rightarrow$ COFIPER & .060 & .046 & 2.008 & $.045 *$ & Supported \\
\hline H3-5 & ENCSR $\rightarrow$ COFIPER & .057 & .043 & 2.027 & $.043 *$ & Supported \\
\hline
\end{tabular}

Squared Multiple Correlation (SMC) of the endogenous variable denoted as $\mathrm{R}^{2}$ ranging from 0 to 1 indicates the effects that the latent variables have on the outcome variables in terms of percentage of variance caused. According to Borenstein and Cohen (1998), the $\mathrm{R}$ square value higher than 0.25 meaning the $\mathrm{R}$ value equals to 


\section{ENTREPRENEURSHIP AND SUSTAINABILITY ISSUES}

ISSN 2345-0282 (online) http://jssidoi.org/jesi/

2020 Volume 8 Number 2 (December)

http://doi.org/10.9770/jesi.2020.8.2(52)

0.50 signifies the large effects in behavioral sciences. In this paper, the $\mathrm{R}^{2}$ value of Corporate Financial Performance variable was 0.51 meaning that $51 \%$ of the total variance in CFP was explained by the structural relations in the official model.

This study's objectives were to establish and empirically test the SEM to explore how managers in Vietnam selfevaluate their companies' financial performance in terms of ROA, ROE and Sales growth with the certain level of CSR awareness and a set of important CSR practices. In the context of managers working diverse businesses operating in Ho Chi Minh City and Binh Duong Province, Vietnam, CSR practices were categorized into four underlying factors, Economic, Legal, Philanthropic and Environmental Corporate Social Responsibilities. The measurement scales were built from multiple researches containing the reliable items for measuring the proposed constructs. As the results, the final structural relation model disclosed the direct causal linkages between Managerial Perceptions and CSR Practices, CSR Practices and CFP and Managerial Perceptions and CFP. Besides, the Managerial Perceptions indirectly influenced the CFP variable through mediating CSR Practices Variables.

The Managerial Perceptions were different for the four identified dimensions of CSR practices which then had different effects on CFP. Although there are a large number of studies about CSR-CFP relationship previously, not many of them have been found to employ the similar constructs and the methodologies, thus the findings would not be equivalently compared. Famiola and Wulansari (2019), Fombrun and Gardberg (2000) and Ullmann (1985) mentioned the essential roles of mediating variables between CSR practices and CFP rather than supported their direct relationship. The research results even contradict the Managerial Opportunism Hypothesis developed by Preston and O'Bannon (1997) that postulated the negative relationship between CSR and CFP, however, partly confirm Menassa and Dagher (2019), Waddock and Graves (1997) that CSR and CFP mutually reinforce each other through a so-called virtuous circle hypothesis. On top of that, this paper advocated the Good Management Theory which posited that good adoption of CSR domains could possibly lead employee's productivity, corporate reputation, customers' satisfaction all of which cascade to financial growth. As the most salient factor explaining the variability of CFP, the economic responsibilities have been deliberated when ones raised a question about the causality. This point was hypothesized under the "Slack Resource Theory", arguing that social performance domains resulted from the availability of slack resources or companies would have more freedom to execute CSR activities once they perform great financially, in other words. Thus, this dimension is rational in this case. Further, the positive relationships between philanthropic CSR and CFP and between environmental CSR and CFP were supported by Seifert et al (2003) and Mengue et al (2005) respectively even though the CSR and CFP measures were not exactly the same. However, there are still opponents refuting these positive linkages who believed that the costs of implementation will hold companies from attaining their financial objectives. On the other hand, the results showed that managers with certain level of understandings of CSR benefits generally engage in CSR practices, which is in line with the Theory of Planned Behavior developed by Ajzen (1991) stating that an individual's behaviors are shaped by the intention toward behavior, beliefs and attitudes. Plus, Waldman et al (2006) in their study asserted that leaders truly play a crucial role in adopting and practicing CSR in their organization.

By and large, all proposed hypotheses were accepted, demonstrating that the surveyed managers perceived, implemented and assessed the payoffs from CSR practices in a positive manner. Nonetheless, while three dimensions that are legal, philanthropic and environmental responsibilities (Martínez García de Leaniz et al., 2019) subtly shadow the effects on CFP, economically orientation is the strongest contributive factors determining the improvement in CFP. The reason mostly comes from the particular business environment in Vietnam currently that micro and small enterprises whose priorities are profits, productivity and efficiency make up more than $96 \%$ of the total registered enterprises in Vietnam (GSO, 2019). In addition, as the results shown 


\section{ENTREPRENEURSHIP AND SUSTAINABILITY ISSUES}

ISSN 2345-0282 (online) http://jssidoi.org/jesi/

2020 Volume 8 Number 2 (December)

http://doi.org/10.9770/jesi.2020.8.2(52)

from Van and Chan (2008), surveyed companies claimed that CSR implementation is a challenging and costly task and Thang (2008) survey of management students revealed the little knowledge about the term CSR itself. Despite that over a decade has passed since their studies and optimistic signals were noticed through this research, still managers need more time to precisely discover and gauge the payoffs from legal, environmental and philanthropic CSR.

\section{Conclusions}

After the discussion of the research results, the authors came up with several suggestions for enterprises and Vietnam government to promote CSR potential benefits.

For the enterprises, making efforts to boost the economic growth should be put at top priority, outshining other types of responsibilities. In other sense, companies need a meticulous and sustainable strategy for organization development. Many approaches that companies can consider to perform their economic responsibilities comprising but not limiting to profits maximization through productivity increase, marketing and sales effectiveness and product and process improvement, business expansion generating more jobs for labors and innovation for the community. Vietnam economy is growing at the fast pace with opened economic policy allowing enterprises to easily adopt and transfer new technologies, run experiments and gaining credits, especially for startups. Thus, companies' most challenging conundrum is to decide how to utilize their own resources, to invest in which assets to yield back the most before deciding which proportion of the profits should return to the society as reciprocation through philanthropic activities. Moreover, the modest positive influences of legal, philanthropic and environmental CSR domains imply that companies need more time and further attempts to practically embed these responsibilities into their corporate strategy. It also requires companies' unceasing efforts to downplay the costs along the way to achieve positive net present value. The role of a leader is strongly emphasized in this paper. To gain higher CFP in terms of ROA, ROE and sales volume, shareholders of a company need to nominate a leader having a strategic vision about CSR and drive the whole corporate to effectively and efficiently exercise CSR practices.

For the government, the critical mission is to aid companies by improving the fairness and transparency in the business environment which equipped companies with adequate conditions to achieve their financial objectives. Plus, Vietnam government needs to strive to cut the cost of legal compliance, especially under the realm of administrative procedure compliance that brings higher optimism to the companies' perception about legal compliance costs and motivation to proactively acting in accordance with laws. Furthermore, government should highlight the role of not only individual citizens but also enterprises in the common efforts of protecting and reforming the environment. By promulgating stricter environmental decrees as well as giving prominence to environment-related initiatives from pioneering enterprises, other following enterprises will have more confidence and inspiration to trigger CSR exercises.

\section{Limitations and future research}

The research is subjected to inevitable shortcomings with the research design and methodology explained as follows. Because the data were collected from managers working in Ho Chi Minh City and Binh Duong Province, Vietnam, research results may not reflect the general cases and be applied to other areas as well as in other developing countries. Moreover, as the sample has great diversity, this study is not centralized around a specific business sector, size, revenue, industry or manager's position. Hence, the effects of CSR practices on CFP might vary as ones trying to look into a narrower scope. 


\section{ENTREPRENEURSHIP AND SUSTAINABILITY ISSUES}

ISSN 2345-0282 (online) http://jssidoi.org/jesi/

2020 Volume 8 Number 2 (December)

http://doi.org/10.9770/jesi.2020.8.2(52)

The paper also faces another problem with the methodology. As surveyed managers gave their answers to the questionnaire completely based on their attitudes and subjective evaluations, a scenario can happen when two or more managers in the same companies see different facts from one fact. It may distort the honesty and objectivity of the company's reality. In spite of the fact that the study successfully demonstrated CSR consideration under managers' prism, it did not answer why managers have such evaluations.

In final words, this study attempted to explain and predict how CFP is impacted by a structural model including managerial perceptions, economic CSR, legal CSR, philanthropic CSR and environmental CSR. In future research, more detailed CSR categories and other control and moderating variables should be integrated to the model to achieve more in-depth knowledge of the CSR-CFP link.

\section{References}

Agle, B.R., Mitchell, R.K., \& Sonnenfeld, J.A. (1999). Who matters to CEOs? An investigation of stakeholder attributes and salience, corpate performance, and CEO values. Academy of Management Journal, 42(5), 507-525.

Ajzen, I. (1991). The theory of planned behavior. Organizational Behavior and Human Decision Processes, 50(2), $179-211$.

Álvarez, M.D., \& Merino, M. (2008). Environmental uncertainty: The side object of perception. Innovar, 18(32), 65-74.

Ambec, S., \& Lanoie, P. (2008). Does it pay to be green? A systematic overview. Academy of Management Perspectives, $22(2), 45-62$.

Banerjee, S.B (2001). Managerial perceptions of corporate environmentalism: Interpretations from industry and strategic implications for organizations. Journal of Management Studies, 38(4), 489-513.

Barnett, M.L., \& Salomon, R.M. (2006). Beyond dichotomy: The curvilinear relationship between social responsibility and financial performance. Strategic Management Journal, 27(11), 1101-1122.

Batool, S., Butt, A., \& Niazi, B. (2016). Types of corporate social responsibility practices across the industry in Pakistan and their effectiveness. Developments in Corporate Governance and Responsibility, 10, 225-246.

Bedeian, A.G. (2002). The dean's disease: How the darker side of power manifests itself in the office of dean. Academy of Management Learning \& Education, 1(2), 164-173.

Borenstein, M., \& Cohen, J. (1988). Statistical power analysis: A computer program. Lawrence Erlbaum.

Bortree, D.S. (2014) The state of CSR communication research: A summary and future direction. Public Relations Journal, 8(3),1-8.

Bowen, H.R., \& Johnson, F.E. (1953). Social responsibility of the businessman. Harper.

Bowen, S.A., \& Heath, R.L. (2005). Issues management, systems, and rhetoric: Exploring the distinction between ethical and legal guidelines at Enron. Journal of Public Affairs, 5(2), 84-98.

Bowie, N. (1995). New directions in corporate social responsibility, in Hoffman, W. M., and Frederick, R.E. (Eds), Business Ethics: Readings and Cases in Corporate Morality. McGraw-Hill.

Brammer, S., \& Millington, A. (2008). Does it pay to be different? An analysis of the relationship between corporate social and financial performance. Strategic Management Journal, 29(12), 1325-1343.

Buchanan, D., \& Huczynski, A. (1997). Organizational behavior: An introductory text. Prentice Hall.

Burton, B.K., \& Hegarty, W.H. (1999). Some determinants of student corporate social responsibility orientation. Business \& Society, 38(2), 188-205. 


\section{ENTREPRENEURSHIP AND SUSTAINABILITY ISSUES}

ISSN 2345-0282 (online) http://jssidoi.org/jesi/

2020 Volume 8 Number 2 (December)

http://doi.org/10.9770/jesi.2020.8.2(52)

Campbell, L., Gulas, C.S., \& Gruca, T.S. (1999). Corporate giving behaviour and decision maker social consciousness. Journal of Business Ethics, 19(4), 375-83.

Carroll, A.B. (1991). The pyramid of corporate social responsibility: Toward the moral management of organizational stakeholders. Business Horizons, 34(4), 39-48.

Child, J. (1972). Organizational Structure, Environment and Performance: The Role of Strategic Choice. Sociology, 6(1), 1-22.

Cordeiro, J., \& Tewari, M. (2015) Firm characteristics, industry context, and investor reactions to environmental CSR: A stakeholder theory approach. Journal of Business Ethics, 130(4), 833-849.

Dahlsrud, A. (2008). How corporate social responsibility is defined: an analysis of 37 definitions. Corporate Social Responsibility \& Environmental Management, 15(1), 1-13.

Deckop, J.R., Merriman, K.K., \& Gupta, S. (2006). The effects of CEO pay structure on corporate social performance. Journal of Management, 32(3), 329-342.

Diamantopoulos, A., \& Siguaw, J.A. (2000). Introducing LISREL: A guide for the uninitiated. Sage.

Downey, H.K., Hellriegel, D., \& Slocum, J.W. (1975). Environmental uncertainty: The construct and its application. Administrative Science Quarterly, 20(4), 613-629.

Du, S., Swaen, V., Lindgreen, A., \& Sen, S. (2013). The roles of leadership styles in corporate social responsibility. Journal of Business Ethics, 114(1), 155-169.

Famiola, M., \& Wulansari, A. (2019). SMEs' social and environmental initiatives in Indonesia: An institutional and resource-based analysis. Social Responsibility Journal, 16(1), 15-27.

Fernando, S., \& Lawrence, S. (2014). A theoretical framework for CSR practices: Integrating legitimacy theory, stakeholder theory and institutional theory. Journal of Theoretical Accounting Research, 10(1), 149-178.

Fombrun, C.J., \& Gardberg, N. (2000). Who's tops in corporate reputation? Corporate Reputation Review, 3(1), $13-17$.

Freeman, R.E. (1984). Strategic management: A stakeholder approach. Pitman, Boston.

General Statistics of Vietnam. Retrieved from https://www.gso.gov.vn/default_en.aspx?tabid=622\&ItemID=18585

Hair, J.F., Black, W.C., Babin, B.J., Anderson, R.E., \& Tatham, R.L. (1998). Multivariate data. Upper Saddle River, NJ: Prentice Hall.

Hair, J.F., Black, W.C., Babin, B.J., \& Anderson, R.E. (2010). Multivariate data analysis. New Jersey, Pearson Prentice Hall.

Harrison, J., \& Boyle, E. (2006) Falling into capability learning traps: The role of the firm's predominant managerial mental models. Management Decision, 44(1), 31-43.

Hegarty, W.H., \& Tihanyi, L. (1999). Surviving the transition: Central European bank executives' view of environmental changes. Journal of World Business, 34(4), 409-422.

Hemingway, C.A., \& Maclagan, P.W. (2004). Managers' personal values as drivers of corporate social responsibility. Journal of Business Ethics, 50(1), 33-44.

Hill, R.C., \& Levenhagen, M. (1995). Metaphors and mental models: Sensemaking and sensegiving in innovative and entrepreneurial activities. Journal of Management, 21(6), 1057-1074.

Ho, N.T.T., \& Yekini, L.S. (2014). Investigating the link between CSR and financial performance: Evidence from Vietnamese listed companies. British Journal of Arts and Social Sciences, 17(1), 85-101.

Hofstede, G. (1980). Motivation, leadership, and organization: Do American theories apply abroad? Organizational Dynamics, 9(1), $42-63$.

Irshad, A., Rahim, A., Khan, M.F., \& Khan, M.M. (2017). The impact of corporate social responsibility on customer satisfaction and customer loyalty, moderating effect of corporate image. City University Research Journal, 1, 63-73. 


\section{ENTREPRENEURSHIP AND SUSTAINABILITY ISSUES}

ISSN 2345-0282 (online) http://jssidoi.org/jesi/

2020 Volume 8 Number 2 (December)

http://doi.org/10.9770/jesi.2020.8.2(52)

Jabnoun, N., \& Al-Tamimi, H.A.H. (2003). Measuring perceived service quality at UAE commercial banks. International Journal of Quality \& Reliability Management, 20(4), 458-72.

Jamali, D., \& Mirshak, R. (2006). Corporate Social Responsibility (CSR): Theory and practice in a developing country context. Journal of Business Ethics, 72(3), 243-262.

Johar, G.V., \& Pham, M.T. (1999). Relatedness, prominence, and constructive sponsor identification. J Mark Res, 36(3), $299-312$.

Kisenyi, V., \& Gray, R. (1998). Social disclosure in Uganda? A research note on investigating absence. Social \& Environmental Accountability Journal, 18(2), 16-18.

Li, J.-Y., Overton, H., \& Bhalla, N. (2020) Communicative action and supportive behaviors for environmental CSR practices: an attitudebased segmentation approach. Corporate Communications: An International Journal, 25(2), 171-186.

Margolis, J.D., \& Walsh, J.P. (2003). Misery loves companies: Rethinking social initiatives by business. Administrative Science Quarterly, $48(2), 268-305$.

Marshall, J., \& Heffes, E.M. (2007). New group pushes 'responsibility officer'. Financial Executive, 23(1), 11-12.

Marta, J., Singhapakdi, A., \& Kraft, K. (2008). Personal characteristics underlying ethical decisions in marketing situations: A survey of small business managers. Journal of Small Business Management, 46(4), 589-606.

Martínez García de Leaniz, P., Herrero Crespo, Á., \& Gómez-López, R. (2019). The role of environmental CSR practices on the formation of behavioral intentions in a certified hotel context. Spanish Journal of Marketing - ESIC, 23(2), 205-226.

McWilliams, A., \& Siegel, D. (1997). The role of money managers in assessing corporate social responsibility research. The Journal of Investing, 6(4), 98-107.

Mengue, B., \& Ozanne, L. (2005). Challenges of the green imperative: A natural resource-based approach to the environmental orientation-business performance relationship. Journal of Business Research, 58(4), 430-438.

Menassa, E., \& Dagher, N. (2019). Determinants of corporate social responsibility disclosures of UAE national banks: A multi-perspective approach. Social Responsibility Journal, 16(5), 631-654.

Menon, A., \& Menon, A. (1997). Enviropreneurial marketing strategy: The emergence of corporate environmentalism as market strategy. Journal of Marketing, 61(1), 51-67.

Milliken, F.J., \& Lant, T.K. (1990). The effect of an organization's recent performance history on strategic persistence and change: The role of managerial interpretations. Leonard N. Stern School of Business, New York University.

Nguyen, B.T.N., Tran, H.T.T., Le, O.H., Nguyen, P.T., Trinh, T.H., \& Le, V. (2015). Association between corporate social responsibility disclosures and firm value-Empirical evidence from Vietnam. International Journal of Accounting \& Financial Reporting, 5(1), 212-228.

Nyaupane, G.P., Morais, D.B., \& Graefe, A.R. (2004). Nature tourism constraints: A cross-activity comparison. Annals of Tourism Research, 31(3), 540-555.

Overton, H.K. (2018) Examining the impact of message frames on information seeking and processing: a new integrated theoretical model. Journal of Communication Management, 22(3), 327-345.

Peterson, R.T., \& Jun, M. (2009). Perceptions on social responsibility: The entrepreneurial vision. Business \& Society, 48(3), 385-405.

Planken, B., Nickerson, C., \& Sahu, S. (2013) CSR across the globe: Dutch and Indian consumers' responses to CSR. International Journal of Organizational Analysis, 21 (3), 357-372.

Preston, L.E., \& O’Bannon, D.P (1997). The corporate social-financial performance relationship. Business \& Society, 36(4), 419-429.

PwC, PricewaterhouseCoopers. Retrieved from https://www.pwc.com/gx/en/ceo-survey/2014/assets/pwc-17th-annual-global-ceo-surveyjan-2014.pdf. 


\section{ENTREPRENEURSHIP AND SUSTAINABILITY ISSUES}

ISSN 2345-0282 (online) http://jssidoi.org/jesi/

2020 Volume 8 Number 2 (December)

http://doi.org/10.9770/jesi.2020.8.2(52)

Quazi, A.M. (2003). Identifying the determinants of corporate managers' perceived social obligations. Management Decision, 41(9), 822831 .

Rokeach, M. (1973). The nature of human values. Free press.

Russo, M.V., \& Fouts, P.A. (1997). A resource-based perspective on corporate environmental performance and profitability. Academy of Management Journal, 40(3), 534-559.

Seifert, B., Morris, S.A., \& Bartkus, B.R. (2003). Comparing big givers and small givers: Financial correlates of corporate philanthropy. Journal of Business Ethics, 45(3), 195-211.

Senge, P.M., \& Sterman, J.D. (1992). Systems thinking and organizational learning: Acting locally and thinking globally in the organization of the future. European Journal of Operational Research, 59(1), 137-150.

Simon, H.A. (1957). Models of man; social and rational. Oxford, England: Wiley.

Singh, S., \& Mittal, S. (2019). Analysis of drivers of CSR practices' implementation among family firms in India: A stakeholder's perspective. International Journal of Organizational Analysis, 27(4), 947-971.

Solomon, R.C. (1994). The new world of business ethics and Free Enterprise in the Global 1990s. Boston.

Thang, T.T.N. (2008). Perception of corporate social responsibility in Vietnam - A study of executive management students. International Vision, 12, 107-118.

Thanh, P.V., \& Podruzsik, S. (2018). CSR in developing countries: Case study in Vietnam. Management, 13(4), $287-300$.

Thomas, A.S., \& Simerly, R.L. (1994). The chief executive officer and corporate social performance: An interdisciplinary examination. Journal of Business Ethics, 13(12), 959-968.

Tran, T.T. (2017). Corporate social responsibility (CSR) situation in Vietnam. Master's Thesis. Faculty of Business Administration Lappeeranta, Saimaa University of Applied Sciences.

Ullmann, A. (1985). Data in search of a theory a critical examination of the relationship among social performance, social disclosure and economic performance. Academy of Management Review, 13(3), 540-577.

Van, N.C., \& Chan, N. (2008). CSR-A model for sustainable social and ecological development in Vietnam? International Vision, 12, 4956.

Waddock, S.A., \& Graves, S.B. (1997). The corporate social performance-financial performance link. Strategic Management Journal, 18(4), 303-319.

Waldman, D.A., Sully de Luque, M., Washburn, N., House, R.J., Adetoun, B., Barrasa, A., \& Wilderom, C.P.M. (2006). Cultural and leadership predictors of corporate social responsibility values of top management: A GLOBE study of 15 countries. Journal of International Business Studies, 37(6), 823-837.

Wahba, H. (2008) Does the market value corporate environmental responsibility? An empirical examination. Corporate Social Responsibility and Environmental Management, 15(2),89-99.

Wang, T.H. (2011). Developing web-based assessment strategies for facilitating junior high school students to perform self-regulated learning in an e-Learning environment. Computers \& Education, 57(2), 1801-1812.

Welford, R., Chan, C., \& Man, M. (2008) Priorities for corporate social responsibility: A survey of businesses and their stakeholders. Corporate Social Responsibility and Environmental Management, 15 (1), 52-62.

Wood, D.J. (1991). Corporate social performance revisited. Academy of Management Review, 16(4), 691-718.

Yusoff, A.R.B.M., Kim, D., Kim, A.P., Shneider, F.K., da Silva, W.J., \& Jang, J. (2015). A high efficiency solution processed polymer inverted triple-junction solar cell exhibiting a power conversion efficiency of 11.83\%. Energy \& Environmental Science, 8(1), 303-316. 


\section{ENTREPRENEURSHIP AND SUSTAINABILITY ISSUES}

ISSN 2345-0282 (online) http://jssidoi.org/jesi/

2020 Volume 8 Number 2 (December)

http://doi.org/10.9770/jesi.2020.8.2(52)

\section{Acknowledgements}

This research is funded by Vietnam National University Ho Chi Minh City (VNU-HCM) under grant number B2020-28-03.

Khuong N. MAI is an associate professor, lecturer and researcher of School of Business Administration, International University, Vietnam National University- Ho Chi Minh City. He has bachelor degree in Tourism and Hospitality Management, master of science degree in leisure, tourism and environment at Wageningen University, The Netherlands, and PhD degree in development management at School of Public Administration of the National Institute of Development Administration (NIDA), Bangkok-Thailand.

ORCID ID: orcid.org/0000-0002-0527-3046

Phuong N.D NGUYEN is a lecturer and researcher of School of Business, International University, Vietnam National University Ho Chi Minh City. He earned his Ph.D in Development Administration at NIDA in Thailand. His major research focuses on public policy, sustainability, corporate strategy, customers' behavior, employee' behavior on commitment, engagement and retention.

ORCID ID: orcid.org/0000-0003-2407-6440

An K.T. NGUYEN is a Ph.D candidate at School of Business, International University, Vietnam National University Ho Chi Minh City.

Ngoc M. TRAN is a graduate student at School of Business, International University, Vietnam National University Ho Chi Minh City.

Make your research more visible, join the Twitter account of ENTREPRENEURSHIP AND SUSTAINABILITY ISSUES: @Entrepr69728810

Copyright (C) 2020 by author(s) and VsI Entrepreneurship and Sustainability Center This work is licensed under the Creative Commons Attribution International License (CC BY). http://creativecommons.org/licenses/by/4.0/

C) (i) Open Access 